\title{
Secularity, Emotion and Law in Ian McEwan's: The Children Act
}

\author{
Bancha Rattanamathwwong (บัญชา รัตนมธุวงศ์) \\ Lecturer, English Department, Faculty of Arts, \\ Chulalongkorn University, Bangkok, Thailand \\ bancha.r@chula.ac.th
}

\begin{abstract}
This paper examines Ian McEwan's The Children Act as a work of fiction that explores the contemporary issue of secularism. My argument is that the novel's exploration of the interplay between law and feelings demonstrates McEwan's attempt to defy the dichotomous quality commonly attributed to law. By juxtaposing the implementation of law and religious practices, the novel's dramatization of the collision between these two forces shows that emotion and feeling are never absent from the allegedly unsympathetic secular civic institution. The realm of law can offer both sympathy and compassion to people who are subject to it.
\end{abstract}

\section{Keywords}

secularity - Ian McEwan - The Children Act

\section{บทคัดย่อ}

ความเป็นฆราวาส อารมณ์ และกฎหมายในนวนิยายเรื่อง The Children Act ของเอียน แม็คคิววัน

บทความนี้มุ่งศึกษานวนิยายเรื่อง The Children Act ของเอียน แม็คคิววันในฐานะเรื่องแต่งที่ นำเสนอประเด็นปัญหาในสังคมร่วมสมัยเกี่ยวกับแนวคิดฆราวาสนิยม ผู้วิจัยโต้แย้งว่าการนำเสนอ บทบาทระหว่างกฎหมายและอารมณ์ความรู้สึกในนวนิยายเรื่องนี้แสดงให้เห็นถึงความ พยายามของแม็คคิววันที่จะทลายแนวคิดแบบขั้วตรงข้ามที่มักถูกนำมาผูกโยงกับกฎหมาย แม็คคิววันเปรียบเทียบการใช้อำนาจทางกฎหมายกับวิธีปฏิบัติทางศาสนาและแสดงให้ผู้อ่านเห็น

(C) BANCHA RATTANAMATHUWONG, 2020 | DOI:10.1163/26659077-02301001

This is an open access article distributed under the terms of the prevailing CC-BY-NC License at the time of publication 
ว่าการตัดสินคดีความทางกฎหมายในศาลซึ่งถือเป็นสถาบันฝ่ายพลเรือนทางฆราวาสนั้นไม่ได้เป็น กระบวนการอันปราศจากอารมณ์และความรู้สึกเสมอไป ตัวกฎหมายเองก็สามารถแสดงความเห็น ใจและความอาทรต่อผู้อยู่ใต้บังคับของกฎหมายได้เช่นกัน

\section{Introduction}

Religious freedom is being threatened. Believers are constantly facing ridicule and persecution while society spirals into moral decline. These discourses, which stress the marginalization of religions and the feeling of disenfranchisement felt by religious adherents, result from the rise of secularism in contemporary society where people have started to embrace a non-religious life as opposed to one guided by religious teachings and the desire for an existence which transcends corporeal reality. Many secularists believe that religious teachings should remain completely separate from civic institutions, such as courts, schools or governments. For instance, creationism should be removed from the school curriculum and people who have no religious affiliation should be allowed to assume important roles in government. To those whose lives revolve around religious spirituality, these scenarios can give rise to a feeling that their beliefs and their modes of existence are under threat. Key to this problem is not merely the question of legal rights but also the affective aspect of the conflict between the realms of religiosity and secularity. Since secularity, which etymologically means the world, prioritizes fulfilment achieved in this world, secularist ideology cannot always accommodate the religious propensities of some people. In fact, secular civic services are also likely to be affectively inadequate for those pursuing otherworldly goals.

This issue of inadequacy is addressed by Winnifred Sullivan in The Impossibility of Religious Freedom (2007). In her book, Sullivan recounts the trial of Warner vs Bota Raton in which she, as a scholar of Religious Studies, served as an expert witness. According to the regulations of the Bota Raton Cemetery in Florida, USA, any memorial that "extend[ed] vertically above the ground" would not be allowed in this nonsectarian cemetery. However, in practice, this rule had not been strictly enforced until the Boca Raton received some complaints from plot owners about nonconforming grave decorations. The decorations mentioned were mostly religious symbols, ranging from statues of the Sacred Heart, Stars of David to statues of the Virgin Mary, etc. After conducting a survey, the City decided that the rule should be followed, leading to a lawsuit between the city and some plot owners. The plaintiffs claimed that the regulations in question were "an unconstitutional and illegal burden on the exercise of religion" $(2007,22)$. 
The technicalities of this case demanded that the plaintiffs proved that their memorials were deemed the "exercise of religion." Eventually, the court concluded that the act of decorating a grave with an above-ground memorial was not an exercise of religion because the exercise of religion only includes conduct "that, while not necessarily compulsory or central to a larger system of religious beliefs, nevertheless reflects some tenet, practice or custom of a larger system of religious beliefs" $(2007,97)$. Sullivan employs this case to posit that the definition of "religion" as defined by the legal institutions in her country is semantically limited. It merely recognizes religions as institutionalized entities even though some scholars insist that a specific demarcating categorization is in no way possible in a pluralist society. From Sullivan's perspective, the narrow positivistic view of secular law fails to take into consideration how one experiences one's spiritual life. She concludes that the plaintiffs in the Warner case needed more than the right to practise their religions. They should have had the right to "life outside the state - the right to live as a self on which many given, as well as chosen, demands are made" $(2007,159)$. Her main suggestion here is that the law must not disregard a subjective demand of a religious subject and the subjectivity, in this context, cannot do away with emotions or the affects of religious adherents. Law itself and its procedures are presented in her work as callous, inhumane, and indifferent state mechanisms symptomatic of the law's secular and textually-driven modus operandi.

Similarly, in response to the Danish cartoon affair, ${ }^{1}$ Saba Mahmood (2013) states that one can never understand how offended a religious subject can feel about a sacrilegious act unless one takes into account "the affective and embodied practices through which a subject comes to relate to a particular sign" (64). In other words, what catalyzed religious subjects' anger in the Danish cartoon affair was the affective injury rather than any violation of religious code (72). Again, conflicts between religions and secularist ideologies are articulated with the specific focus on affective aspects. For both Mahmood and Sullivan, secular institutions and secular society seem to lack the kinds of sensitivities a religious subject needs.

Does secularity always connote apathy? Can a secular legal system attend to the needs of the religious? Ian McEwan's novel, The Children Act, addresses these questions by undoing the polarizing idea about the objective nature of the law and the emotional quality commonly found in religions. While Mahmood and Sullivan suggest that secular institutions are quintessentially flawed

1 In 2005, Jyllands-Posten, a Danish newspaper, published a series of cartoons which depicted and satirized the Prophet Muhammad. The cartoons sparked protests and caused violent riots in many countries. 
and insufficient in their consideration of people's feelings, McEwan presents the idea that the secular legal system can also serve as a medium of compassion because law is created to guarantee a person's well-being. Law might not be able to protect the feelings of all the parties involved but the rationale behind its creation is not to champion heartless objectivity. As shown in The Children Act, judges are in a position to mediate the compassion embodied within the law. Employing the theory of emotions together with the theory of secularism, I hope to contribute to the current scholarship on McEwan's depiction of an immanent life in which the affective life of a secular subject within a secular space still remains unexplored. My argument is that McEwan's novel expounds the author's view that secularity is not and should not be equated with an absence of feeling or compassion. In fact, secular principles represented by the law and legal procedures in the novel are capable of "caring" about people more than religions can.

My argument and my focus will differ from those of other scholars, such as Arthur Bradley and Andrew Tate (2010) and Justin Neuman (2014), whose works explore the secular proclivity in McEwan's novels. The arguments put forth in their works are mainly through a deconstructive lens, suggesting the conceptual flaws in McEwan's treatment of secularity. For Bradley and Tate, McEwan's novels usually reveal the author's faith in the redemptive power of fiction and thereby end up undermining the notion of freedom from religion espoused by the author himself. Similarly, Neuman also points out how the temporal perception of the main character in McEwan's Saturday does not differ much from a religious subject's conception of temporality. Unlike these scholarly criticisms, my reading of McEwan's The Children Act will not be against the grain. In other words, my analysis, which primarily focuses on the roles emotions play in the secular domains of civic institutions, will mainly explicate how secularism can still be celebrated and advocated in McEwan's narratives despite the problematic aspects of his secularism.

\section{When Fiona Meets Adam: An Allegorical Clash between Law and Religion}

The conflict in The Children Act allegorizes the clash between the religious and the secular. The story is told from the point of view of Fiona Maye, a High Court judge whose marital life is on the edge of collapse because Jack, her husband and a history professor, wants to have an affair with another woman. Jack feels that their conjugal life has become insipid. Still, with an extraordinary attempt at decency, he asks for his wife's permission to embark on his late life romantic 
pursuit. His request undoubtedly infuriates Fiona. While she is trying to figure out what has gone wrong with her marriage she receives a new case to preside over. Adam Henry, a seventeen-year-old boy, is suffering from leukemia but has chosen not to undergo the blood transfusion procedure required for his treatment. His refusal is mainly because of his religious beliefs. Like his parents, Adam is a strict member of the Jehovah's Witnesses, a Christian denomination that because of its belief and its interpretation of the Bible, sees blood transfusion as a sinful act.

This collision between religious beliefs and civic institutions revolves around the issue of pragmatism. As Adam's condition worsens, the medical staff cannot afford to lose time. Consequently, Fiona must make a decision that will determine the life and survival of Adam. Unable to decide, she visits the boy in hospital in order to have a conversation with him and gauge his state of mind. To her surprise, the boy she meets turns out to be intelligent, articulate, innocent and determined to die for his faith; nevertheless, Fiona eventually authorizes the medical staff to proceed with their treatment. Adam is cured and is restored to health.

Still, the conflict of the story does not simply end in court. The clash between civic operation and religious practices is resolved only to be followed by another conflict when Adam, after being treated, loses faith in his religion and comes to idolize Fiona, his saviour. Admitting to the absurdity of his faith, Adam asks if he can go and live with Fiona. On the spur of the moment, rejecting him and sending him away, the judge kisses her young admirer, an action that even Fiona herself deems to be impulsive and totally out of character. She then tries to avoid communicating with Adam and continues with her life, which, at that point, already has her husband and her on speaking terms. Some months later, as she is about to take part in a musical performance in front of her colleagues, Fiona is informed that Adam's leukemia has returned and he has passed away. No longer a minor, he had been entitled to refuse treatment. Fiona is devastated because she believes that she played a part in Adam's suicidal decision. The story concludes with Fiona going back home and telling her husband the story of this case as well as the intimate moment she shared with the boy. The couple are reconciled when Jack promises to love his wife after listening to her recounting the story of Adam's case.

The characters in the story are highly allegorical. Both Fiona and the Henrys incarnate diametrically opposed ideological stances. Fiona is portrayed both as a capable, workaholic member of the judiciary and as a cold and frigid woman. The opening of the novel reinforces the generalized view that the realm of legality is one of emotional detachment. When Jack confronts Fiona and asks for her permission to venture into a more exciting sex life with another 
woman, he accuses his wife of indifference and apathy. Although Jack's request is undeniably unacceptable on any grounds, those familiar with McEwan's novels will be aware that sexual intercourse in many of McEwan's novels is rarely depicted as a shameful obscenity but is usually presented as a natural and life-affirming human interaction. In The Children Act, Jack's frustration over his lackadaisical marital life could suggest Fiona's own emotional distance and her incapacity to enjoy and engage with the pleasures that life can yield. Even when she is asked by Jack when they last made love, Fiona still cannot stop thinking about work (4). The first-person narrative enables the readers to look into Fiona's consciousness, which reveals that, even in a critical situation where her marital life is at stake, she cannot completely divorce her mind from her work:

She believed she brought reasonableness to hopeless situations. On the whole, she believed in the provisions of family law. In her optimistic moments, she took it as a significant marker in civilization's progress to fix in the statutes the child's needs above its parents. Her days were full, and in the evenings recently, various dinners, something at Middle Temple for a retiring colleague, a concert at King Place (Schubert, Scriabin), and taxis, Tube trains, dry-cleaning to collect, a letter to draft about a special school for the cleaning lady's autistic son, and finally sleep. Where was the sex? At that moment, she couldn't recall. $\left(5^{-6}\right)$

Fiona's train of thought lends a certain validity to Jack's accusation. Losing herself in her work and her social life, Fiona forsakes her family life, the private realm, which is associated with personal fulfilment. Instead, she takes pride in her ability to make rational legal judgments and her commitment to the progress of civilization. Fiona's contemplation of her unbalanced life presents the readers with a classic dichotomy with regard to the issue of secularism: the clash between reason and emotion. Fiona's situation implies that the longer one plunges oneself into a milieu operated by rationalism, the more that person will lose the ability to experience emotion. At first glance, Fiona seems to be the embodiment of the defect of law: rational but distant, objective but uncaring, and good-willed yet never passionate.

However, McEwan characterizes Fiona as such in order to undermine these polarizing oppositions later. As the story unfolds, readers learn that Fiona is not just a flat allegorical character who encapsulates the apathetic quality of law. Her emotional detachment, as readers find out later in the story, results from a case concerning Siamese twins for which she was appointed judge. In this legal case, two boys, Matthew and Mark, were born sharing one torso. With 
most of his internal organs unable to function on their own, Matthew relies on his twin brother to sustain his life. However, Matthew's dependence on Mark is parasitic as the former's survival comes at the expense of Mark's sustenance. All the food that Mark consumes feeds his brother but not himself. The medical staff believe that if this situation continues, the two brothers will soon die. As a result, they ask the twins' parents to save Mark by separating them, which will entail the death of Matthew. Heartless as it may seem, Mark, at least, will be able to grow up and become a healthy adult. However, the parents, as devout Catholics, refuse to let the medical staff carry out the operation on the grounds that they consider this medical decision a form of murder, a sinful act according to their religious belief. Fiona, as the judge in this case, finds herself somewhere between Scylla and Charybdis. In her judgment she concludes that the medical staff should be permitted to save the life of Matthew, referring to the "doctrine of necessity," or "an idea established in common law that in certain limited circumstances, which no parliament would ever care to define, it was permissible to break the criminal law to prevent a greater evil" (29). Her reasoning is that Matthew is a party with no interest in this case because his fate is already sealed whether an operation can be performed to save Mark or not. The difference this operation can make will only have an effect on the survival of Mark:

Regarding the all-important matter of intent, the purpose of the surgery is not to kill Matthew but to save Mark. Matthew, in all his helplessness, was killing Mark and the doctors must be allowed to come to Mark's defence to remove a threat of fatal harm. Matthew would perish after the separation not because he was purposefully murdered but because on his own he was incapable of flourishing. (29)

McEwan depolarizes two stereotypical ideas here: one about law itself and one about those who represent and work under it. Firstly, he challenges the general view people have towards the unbending and callous nature of law. Fiona's reasoning and the "doctrine of necessity" she alludes to may be utilitarian and pragmatic per se; mathematically simple, saving one life proves better than losing two. This notion of pragmatic rationalism is highly valued as a secular concept since, in terms of historical development, its tenets have contributed to the emergence of freedom from religious dogmatism. As Janet Jakobsen and Ann Pellegrini put it, in the process of modernization, the exercise of logical judgment independent of religious dogmas constitutes an important part of the secularization narrative $(2008,4-5)$. Still, this doctrine of necessity, which seems extremely rigid, paradoxically epitomizes the flexibility that law 
can afford as well. Usually, necessity suggests the absence of choice; however, the doctrine of necessity here makes it possible for legal officials to disobey the legal power governing them. By including this detail, McEwan demonstrates that rigidity is not the only thing that the law can offer to society.

Moreover, McEwan also defies the stereotypes of legal officials recurrent in media and discourse communities in which the implementation of secularist practices has become the subject of debate. When in court, Fiona assumes the secular role associated with legal institutions. Her main duty is to form a judgment which mainly caters to the realm of the living. When a conflict arises from religious teachings and secular questions of life or death, her judgement must remain secular by disregarding the religious beliefs, which lose touch with the exigent concerns of the worldly. For some people, such as the devout in the story who send Fiona disparaging letters condemning her decision, it is easy to align Fiona's role with the dichotomous stereotype stated earlier in this essay. Yet, the narrative, which is told from Fiona's point of view, reveals that the protagonist is affected and troubled by this decision too. No matter how one puts it, undeniably, she plays a part in terminating the life of the young Matthew. This feeling of contrition results in Fiona's defeatist attitude towards life. Whilst Jack's reprimand that his wife has turned cold seems to point towards a generalizing and polarizing negative attitude towards law as expressed in Sullivan's and Mahmood's arguments, the explanation from Fiona's side reminds readers that the scene and place of all legal operations can never rid themselves of all affective dramas. Those working for secular civic institutions, too, are affective beings capable of being affected by emotions.

On the other hand, Adam Henry and his family represent the opposing side of the spectrum but their characterization is given less complexity in comparison with the multi-faceted depiction of Fiona. Pious and naive, Adam is ready to die for his beliefs. Naivety, defiance, and liveliness are his remarkable qualities. This boy, who loves poetry and music, exudes sublimity in the same way that religiosity speaks spiritually to its subjects. Yet, his blind determination bespeaks the dogmatic nature of the side he embodies. Similarly, when asked about the reason behind Adam's stubbornness, his father can merely parrot the principles they are taught to believe: “...blood is the essence of what's human. It's soul, it's life itself. And just as life is sacred, so is blood... Mixing your own blood with the blood of an animal or another human being is pollution, contamination. It's a rejection of the Creator's wonderful gift. That's why God specifically forbids it in Genesis and Leviticus and Acts" (78). His answer does not address the condition of his son at all. This assertion, which reflects how he views the teaching of his religion as an axiom, accentuates belief completely divorced from the reality of life and the pragmatics of the world. This issue 
is particularly poignant for McEwan, who, in his article published after the 9/11 terrorist attack, expressed the importance of empathy and compassion as a key that can combat the hatred and fear instigated by religious fundamentalism:

If the hijackers had been able to imagine themselves into the thoughts and feelings of the passengers, they would have been unable to proceed. It is hard to be cruel once you permit yourself to enter the mind of your victim. Imagining what it is like to be someone other than yourself is at the core of our humanity. It is the essence of compassion, and it is the beginning of morality.

The hijackers used fanatical certainty, misplaced religious faith, and dehumanising hatred to purge themselves of the human instinct for empathy. Among their crimes was a failure of the imagination. As for their victims in the planes and in the towers, in their terror they would not have felt it at the time, but those snatched and anguished assertions of love were their defiance. (2001)

Blind faith leads to one's failure to see the value of life. This inability to appreciate the worldly value of living prevents terrorists from having empathy. According to McEwan, this empathy should be instinctive and can serve as the foundation of non-religious morality. In contrast, the religious worldviews held by terrorists are counterintuitive, numbing their basic human common sense. In the context of the novel, the counterintuitive facet of religious belief manifests itself in the inflexibility of the religious principles to which the Henrys adhere. In fact, their strict piety does not differ much from the law it opposes because religion, like law, is also operated by sets of rules under which its principles are treated as inviolable. With his allegorizing narrative, McEwan succeeds in shifting the dynamic of dichotomization at issue. In simpler terms, the author reveals that, in some contexts, religion itself may turn out to be more unbending and hence more intractable than law.

Feeling Unbound: The Role of Compassion in the Legal Space

In dealing with Henry's complicated situation, Fiona needs to exercise careful judgment that involves prioritizing the various interests of all the parties involved. Moreover, she also needs to find the legal principles to justify it. The situation in this story underscores the benign nature of secular law contrary to Sullivan's view. As echoed in the works of Martha Nussbaum, legal processes are never devoid of appraisals involving emotions. For Nussbaum, compassion 
is indispensable, and the attempt to do away with sympathy will result in the violation of people's basic rights $(2006,56)$. This postulation is an extension of her idea in Upheavals of Thoughts that our emotions are predicated upon appraisals. According to Nussbaum, emotions usually involve "judgment about important things, judgment in which, appraising an external object as salient for our own well-being," (2001, 19). In other words, emotions and rational judgment may not always be mutually exclusive. In McEwan's story, the interaction between Fiona and Adam suggests that the sensible judgment that saves Adam's life results from Fiona's exercise of compassion, a concept which I will elaborate on later.

In order to explore the dynamic of emotions in the novel, Fiona's judgment and the process by which she reaches her conclusion that Adam's treatment should be authorized merit close examination. In the court scene, the representatives of the secular institutions are revealed to be more flexible and emotionally caring than their religious counterparts. The hearing starts with the interview of Rodney Carter, the doctor who is responsible for the treatment of Adam Henry. Frustrated with his patient's unreasonable stance, Carter can be regarded as an allegorical character representing scientific knowledge. With the juxtaposition between Carter and the Henrys, McEwan defies the common discourses used by many religious fundamentalists that science, like law, is a heartless and uncaring agent. The doctor's emotional investment in the wellbeing of his patient accentuates the humane side of the medical institution whose duty is to prolong one's life. In contrast, Leslie Grieve, the Henrys' lawyer, does the opposite. The lawyer only focuses on winning the case and shows no interest in the fact that the boy is going to lose his life. Ironically, a suicidal exploit, which would be considered a sin in many religions, is tolerated as long as the subject does not violate some rules in the teachings. The lawyer even goes so far as to discredit the hospital staff by selectively citing dubious scientific research in order to insinuate that the staff's decision to treat the boy with a blood transfusion could be unsafe and detrimental to the patient; nevertheless, he blindly refuses to address the possibility of young Adam's death in the case when treatment is not administered in a timely manner. Grieve's approach to Adam's case exemplifies the selective approach of textual interpretations commonly found among religious fundamentalists. In addition, the lawyer also claims that the boy should be allowed to exercise his fundamental right and not allowing him to do so would "constitute a trespass of the person, or indeed an assault of that person" (71). Grieve's argument and his treatment of legal texts suggests that the law can be misused for an extreme purpose. The situation sheds light on the danger of the literal interpretation of legal texts. Far from being a perfect system, the law is subject to interpretation. As a result, 
the implementation of law should not always follow the fixed meaning of the text but requires careful consideration of the rationale behind it. In making a legal judgment, legal officials need to ask themselves why a particular set of laws has been created and what it aims to protect. As shown in Fiona's decision to authorize the medical staff to treat the boy, the protagonist gives priority to the well-being of the boy, a minor whom the Children Act was created to protect.

Since the scientific information and the legal technicalities used by both medical staff and the Henrys' lawyer do not adequately address Adam's mentality that drives him to his "martyrdom," Fiona deems it best to examine the emotional and mental state of Adam himself. This gesture highlights the fact that legal procedure does not always disregard the individuality of those whose life depends upon it. Fiona asks the doctor if the boy is aware of the condition he has to suffer before dying. As a legal authority, she recognizes the importance of thoroughly evaluating the state of mind of the boy and, therefore, decides to visit Adam herself in order to assess his mental state before making a ruling. Surprisingly, the boy appears very intelligent and articulate. He is also a talented young boy who can play the violin and write poetry. He is, however, adamant and firm in his decision of martyrdom, and at one point Fiona even questions herself whether it is really worth the trouble of going to great lengths to save the boy from himself:

The blasphemous notion came to her that it didn't much matter either way whether the boy lived or died. Everything would be much the same. Profound sorrow, bitter regret perhaps, fond memories, then life would plunge on and all three would mean less and less as those who loved him aged and died, until they meant nothing at all. Religions, moral systems, her own included, were like peaks in a dense mountain range seen from a great distance, none obviously higher, more important, truer than another. What was to judge? ( 116)

Her comparison of this nihilistic contemplation to a blasphemy demonstrates that giving up on life is more morally unacceptable than abandoning it for the sake of one's faith. Human life can be inconsequential and even the humanistic mode of thinking advocated by secularism cannot fully save lives from oblivion either. Nevertheless, Fiona realizes that her duty as a judge is also to protect the boy. Given this logic, she then proceeds to make her ruling. Her eloquent judicial statement reveals that the will of law is after all to allow the authority to protect the welfare of people. In order to justify her decision, Fiona reminds the spectators in the court that the will of the law must surpass and be 
given priority before any legal technicalities deployed by Grieve. In arguing for Adam's right to refuse treatment from the medical staff because the boy is soon to attain legal age, Grieve quotes section 8 of the Family Law Reform Act of 1969, which states, "The consent of a minor who has attained the age of sixteen years to any surgical, medical, or dental treatment which, in the absence of consent, would constitute a trespass to his person, shall be as effective as it would be if he were of full age" (88). Grieve then concludes that, by refusing to accept Adam's decision, which according to Grieve is an "informed" decision, the court runs the risk of "undermining an individual's right to refuse treatment" (90). Grieve's line of reasoning both stretches logic and goes against the will of the quoted clause, which mainly focuses on consent, not the absence of it. The will of this clause is meant to facilitate the authorization of treatment and by no means should it be used to legitimize the refusal of medical care. Grieve's exploitation of legal technicality here illustrates his wilful indifference to the intention of the law which he asks the court to respect.

In contrast, Fiona's judgment underscores the capacity of the law to take into account the human aspect of the subject it governs. In her statement, Fiona chooses to base her judgment on the decision of Justice Ward included in the Children Act of 1989, which states, "The welfare of the child therefore dominates my decision, and I must decide what E's welfare dictates" (125). In tandem with this principle, Fiona eventually asserts that, in spite of his intelligence and maturity, Adam does not know enough about life to make a life-or-death decision:

...This court takes no view on the afterlife, which in any event A will discover, or fail to discover, for himself one day. Meanwhile, assuming a good recovery, his welfare is better served by his love of poetry, by his newly found passion for the violin, by the exercise of his lively intelligence and the expressions of a playful, affectionate nature, and by all of life and love that lie ahead of him. In short, I find that A[Adam], his parents and the elders of the church have made a decision which is hostile to A's welfare, which is this court's paramount consideration. He must be protected from such a decision. He must be protected from his religion and from himself. (126-127)

Unlike the blunt and one-dimensional interpretation of law by Grieve, Fiona's take on the function of law proves more profound. She does not just blindly adhere to the textualism of the legal language. Instead, the judge points out that the duty of the law is to protect the welfare of children, the foundation upon which the principle deployed by Grieve is also predicated upon. In other 
words, Fiona treats the law as a tool while law to Grieve is deployed as a sacred regulation.

In addition, Fiona's rationale also shows that legal judgment can be driven by compassion. While Nussbaum's general conceptualization of emotions in relation to an evaluative process which determines what is important to a subject seems to stress the egocentric nature of emotions, her discussion of "compassion" in Upheavals of Thoughts suggests that emotive judgment is not only limited to what is important to the subject. Compassion, which Nussbaum aligns with "sympathy," involves "a judgment that the other person's distress is bad" (2001, 302). Nussbaum further adumbrates the three cognitive requirements that can stir up a feeling of compassion: "The first cognitive requirement of compassion is a belief or appraisal that the suffering is serious rather than trivial. The second is the belief that the person does not deserve the suffering. The third is the belief that the possibilities of the person who experiences the emotion are similar to the sufferer $(2001,306)$." In the context of the novel, the third requirement may not be as relevant as the first two because Fiona's compassion has gone beyond the level of personal empathy. Her concern for Adam's well-being does not merely result from her personal feelings but also from her professional status as the protector of the secular law. As someone who enforces a law that aims to protect the welfare of a minor, Fiona's statement in her ruling demonstrates that her decision is made out of her compassion in the name of law as it resonates with the two requirements posited by Nussbaum. Fiona first recognizes that Adam does not deserve to be in the situation he is in. Fiona's words imply that Adam's suicidal propensity results from the indoctrination he has been subject to since childhood. Also, it is undeniable that Adam's situation can be considered serious enough. Seriousness does not merely deal with the exigency of the situation. As pointed out by Nussbaum, it can be determined by the degree to which a distressing situation can forestall the "flourishing" of the person in question $(2001,307)$. This is most essential in Adam's case because his suicidal inclination entails the worst outcome possible as it will deprive him of the possibility to "flourish," which in Adam's case means his ability to live his life, to develop his interests in arts and music, and to hone his intellect. The life that Fiona intends to protect in the name of law is an immanent one as opposed to its otherworldly counterpart. The physical well-being of an individual comes before anything else and law must guarantee that one's decision to end one's life must be well-informed and result from the careful exercise of rationality, not being misguided by principles that have no bearing on the physical world.

It is worth noting that the difference between Fiona's and Grieve's approach on the power of law also resonates with the concept of "heteronomy" discussed 
by Stathis Gourgouris in Lessons in Secular Criticism. According to Gourgouris, heteronomy can be defined as "the very moment a society refuses to acknowledge that it and no one else has created the law of its God, its state, or its universe" $(2013,45)$. This notion is the opposite of "autonomy." Heteronomy reflects the society's failure to admit that it is in actuality an independent entity. This failure will eventually entails the advent of a sanctified governing rule under which a society becomes slavish to the product of its creation. Gourgouris also emphasizes, "a society that claims that the Law - any mode of law, "secular" or "sacred"-is autonomous is not an autonomous society" $(2013,44)$. Autonomy hence is equated with constantly questioning and challenging the authority of the absolute. For Gourgouris, this is a practice that embodies the spirit of secularity. As he puts it, secular criticism means "a practice that defies mastery," which is "skeptical to the core" $(2013,22)$. While Gourgouris's argument mostly focuses on the sacred status of religion, this concept is applicable to all types of governing rules including the secular law itself. In deciding to treat law as merely a tool to offer humanitarian justice, Fiona demonstrates that law should only serve as a tool. It must not assume an absolute and unquestionable status that may give rise to a heteronomous political or social conditions. Like religion, its power should be limited. Legal authority should not transcend the will and the rationale for which it is created. Law's main duty is to save life, be it the life of an individual or the lives of general people in society. This is when law exhibits compassion to its subjects.

With regard to the role of emotions in Adam's case, religion is ironically presented as the mechanism that denies people the possibility of empathy. The religious leaders who are acquainted with the Henrys keep saying that Adam's death should be welcomed while the boy's parents are not portrayed as reasonable guardians either. Their parental instinct is the price they have to pay for their piety. In the letter that Adam writes to Fiona, he tells her about the distressing truth that he learns after the authorization of his treatment. Like Fiona, Adam's parents do not want him to die but they cannot muster the courage to defy the rule of their own religion. As a consequence, they go to the court, hoping that the judge will order the transfusion. In other words, since they do not want to violate their religious rules by themselves, they want someone else to do it for them, which in this case is the court. What is brought to light in this situation is the emotional irresponsibility of Adam's parents. Neither refuses to shoulder basic parental responsibility but they also try to avoid having to deal with the shame, either social or personal, that may come, should they want to save their child. The sinister side of religious faith presented in this fiasco is that it can cloud even something as basic as parental instinct. This is the most nightmarish scenario blind faith can entail from McEwan's point of 
view. Religious faith can take away love and empathy one is supposed to have for one's own flesh and blood.

\section{$4 \quad$ Outside the Courtroom}

After Adam becomes disillusioned with his parents' cowardice, he abandons his faith and goes back to normal life. At first, everything goes well, yet, unaccustomed to life without religious faith, the boy feels disorientated. He feels the need to look for someone who can help him navigate and find his place in the immanent world he has woken up to. It is not surprising that he chooses to turn to Fiona, his saviour. From the boy's point of view, Fiona assumes an authoritative role. Upon entering into his world, she shatters all of the delusions he has been made to believe:

They [Adam's parents] love me. Why didn't they say that, instead of going on about the joys of heaven? That's when I saw it as an ordinary human thing. Ordinary and good. It wasn't about God at all. That was just silly. It was like a grown-up had come into a room full of kids who are making each other miserable and said, Come on, stop all the nonsense, it's teatime! You were the grown-up. You knew all along but you didn't say. You just asked questions and listened. All of life and love that lie ahead of him - that's what you wrote. That was your 'thing.' And my revelation. From “The Salley Gardens' onward.” (170)

Even though the boy claims that he is disenchanted with religion and has abandoned his faith, his statement is still redolent of religious sentiments. Fiona is described as a god-like figure, authoritative and wise. Adam's use of the word "revelation" to describe his epiphanic experience with William Butler Yeats' poem also carries a religious undertone, accentuating the fact that, even though he has turned down God, his worldview is still entrapped within a transcendental frame. This condition results in Adam's tragic maturation. As long as he cannot rid himself of this preoccupation to be guided by a person or an entity, he will not be able to lead an existentially independent life. Attaining the age of 18 does not mean that he is mentally prepared for a world marked by loneliness, meaninglessness and absurdity. Adam's suicidal decision not to receive treatment at the end of the novel suggests the defeat of those who fail to free themselves from the religious propensity instilled in them.

Still, Adam is not the only disorientated person in this situation. Towards the end of the novel, Fiona is not presented as a strong and firm woman either. 
She too feels confused by Adam's admiration for her and hence tries to distance herself from the boy. Biwu Shang argues that the ending of the novel can be a lesson for Fiona, who needs to realize that the protection of children's welfare should also be practised outside the court:

...Fiona's understanding of the child's welfare is limited: she tries her best to protect the children in court, but ignores them outside the court. The death of Adam is an example revealing her limited understanding of the child's welfare. When he is alive, Adam tells Fiona that "my parents' religion was a poison and you were the antidote" (168). Hence I argue that Fiona's refusal to reply to Adam and her turning him back to his parents almost equals forcing him to take poison. In other words, it is Fiona who has played a larger part in Adam's death, which accounts for her sadness and regret. (2015)

While I agree with Shang that the dilemma Fiona faces after her ruling poses an ethical question, it is worth noting that Fiona's situation is very unusual and too complicated to be explored only in terms of professional ethics. Fiona's state of discombobulation is presented along with that of Adam. McEwan juxtaposes the different ways in which these two characters deal with the absence of guidance. The juxtaposition between a disorientated secular subject and a disorientated religious subject reveals the triumph of secular values in spite of its imperfect nature. Fiona is at her most rational and practical self when she acts in the name of law. In the courtroom, Fiona may always be in control of what she is going to do. However, outside her professional domain, she has her own vulnerability and may not always have a clear sense of direction. This idea is buttressed by the scene in which Fiona gets carried away and kisses Adam, a transgressive gesture that is shocking even to Fiona herself. Her failure to compose herself when she is not in her element indicates that, like the secular values that she represents, Fiona does not always have an answer for everything in the way that Adam wants her to. Still, this does not mean that the author is trying to undermine his own advocacy of rationalism and secularism. McEwan just gives us a realistic portrayal of immanent life filled with uncertainty and unpredictability. In addition, Fiona's rejection of Adam towards the end of the novel also reminds the readers of the compassion that the law can provide. While Fiona's indifference to Adam's emotional needs may point out the inadequacy of law that cannot extend its wings to protect its subjects in every aspect of their life, it paradoxically celebrates the possibility of compassion made possible by secular and impartial law too. After all, in the entire course of the novel, the courtroom is the only place where rationality and compassion 
are allowed to co-exist and reign supreme, enabling Fiona to save Adam from his religious fervor.

\section{Conclusion: Out of Eden}

What then can we make of the fact that the law eventually fails to save Adam after he turns 18? Does it mean that the law is ultimately an unreliable device? I contend that it is not the case as there is no law that is perfect and encompassing enough. This is also the gist of secularity; One's strength is shown through living in a world that is far from perfect. The difference between the situation of Adam before and after he turns 18 is that, in the former, his situation requires that he is at the mercy of others, the legal authority, while, after turning 18 , he assumes full agency and is no longer subject to the protection of the Children Act. This means that law allows for compassion only in cases where it is called for and given permission so to do.

The notion of imperfectibility surfaces not only in the novel's treatment of law but also in other aspects of the main character's' life too. After the unexpected incident with Adam, Fiona realizes that she herself is also a flawed human being. With this realization, the novel ends with a reconciliation between Fiona and her husband. Fiona decides to share all the story of her and the unfortunate young boy with Jack, who promises to love her no matter how terrible the story she is going to tell him may be.

They lay face-to-face in the semi-darkness, and while the great raincleansed city beyond the room settled to its softer nocturnal rhythms and their marriage uneasily resumed, she told him in a steady quiet voice of her shame, of sweet boy's passion for life and her part in his death. (221)

The ending of the novel is reminiscent of Matthew Arnold's "Dover Beach," which is also used in another of McEwan's novels, Saturday. The speaker in the poem asks his lover that they stay true to each other as the declining sea of faith before them affords the couple neither signs of hope nor spiritual comfort. Similarly, in The Children Act, McEwan gives us the modern version of the couple against the world in which religious faith offers no spiritual solace. Uncertain about what lies ahead, the couple here decide to hold on to each other. Even though their experience tells them that neither is perfect, their resumed love at least will allow them to help each other anchor themselves in this disorientating world and thereby protect them from the existential angst that leads to Adam's fall. 


\section{References}

Bradley, Arthur and Andrew Tate. 2010. The New Atheist Novel: Fiction, Philosophy, and Polemic after 9/11. London: Continuum.

Gourgouris, Stathis. 2013. Lessons in Secular Criticism. New York: Fordham University Press.

Jakobsen, Janet and Ann Pellegrini. 2008. “Introduction: Time Like These.” Secularisms, 1-35. Durham: Duke University Press.

Mahmood, Saba. 2013. Religious "Reason and Secular Affect: An Incommensurable Divide?" In Is Critique Secular?: Blasphemy, Injury, and Free Speech, 58-94. New York: Fordham University Press.

McEwan, Ian. 2001. "Only Love and then Oblivion." The Guardian. Retrieved from https://www.theguardian.com/world/2001/sep/15/september11.politics philosophy and society.

McEwan, Ian. 2014. The Children Act. New York: Nan A. Talese/ Doubleday.

Neuman, Justin. 2014. Fiction Beyond Secularism. Evanston: Northwestern University Press.

Nussbaum, Martha. 2001. Upheavals of Thoughts: The Intelligence of Emotions. Cambridge: Cambridge University Press.

Nussbaum, Martha. 2006. Hiding from Humanity. Princeton: Princeton University Press.

Shang, Biwu. 2015. "Ethical Dilemma and Ethical Epiphany in McEwan's The Children Act." CLCWeb: Comparative Literature and Culture 17(5). http://docs.lib.purdue.edu/ clcweb/voliz/iss5/12/.

Sullivan, Winnifred. 2007. The Impossibility of Religious Freedom. Princeton: Princeton University Press. 